\title{
Gregor Mendel and the History of Heredity ${ }^{1}$
}

Staffan Müller-Wille, University of Exeter, sewm201@ex.ac.uk

\section{Abstract}

Gregor Mendel's paper "Experiments on Plant Hybrids" (1866) has become a paradigmatic case in the historiography of the life sciences because production and reception of a "discovery" sharply fell apart, thus raising fundamental questions about the relationship between scientific achievement and "its" time. In this chapter, I am providing an overview of answers that have been given to these questions by various historians. In a first section, I cover commentators who have claimed that Mendel was "ahead" of his time, and that contemporaries failed to recognize his achievement. I then move on to scholars and scientists who argued against this position, claiming that Mendel was not anticipating twentieth-century genetics, but was in fact representative of an older research tradition. In a last step, I turn to the more recent cultural history of heredity according to which Mendel was embedded in a local culture that combined a variety of advanced and traditional strands of nineteenth-century life-sciences. Overall, I am arguing that one should not overestimate the coherence and dominance of presumed "paradigms", "epistemes" or "styles" in biology.

\footnotetext{
${ }^{1}$ Published as „Gregor Mendel and the History of Heredity," in Michael R. Dietrich, Mark Borello (eds.), The Historiography of Biology, New York: Springer, 2018, https: / / doi.org/10.1007/978-3-319-74456-8_8-1.
} 
Ihr Lettern, meines Forschens Sprossen ...2

Gregor Mendel, 1830s

\section{Introduction}

There is no doubt that Gregor Mendel was a child of the nineteenth century. In 1822, he was born into a family of ethnically German small holders in Hynčice (German: Heinzingen) in northeastern Moravia (today Czech Republic), joined the Augustinian Abbey St. Thomas in Brno (Brünn) in 1843, received a thorough education in natural sciences at Vienna University, and finally rose to the position of abbot, which he held until his death in 1884. Like countless contemporaries, he was a keen naturalist, joined local associations for natural history and the promotion of agriculture and industry, and published occasional notes and essays on agricultural pests, plant hybridization, and meteorology. Nothing in Mendel's biography-including perusal of the Emperor Ferdinand Northern Railway to visit the libraries of Vienna and participation in a group tour to see the Great Exhibition in London in 1862-points beyond the intellectual

\footnotetext{
${ }^{2}$ First line from a poem that Gregor Mendel sketched in the late 1830s during his time at the gymnasium of Opava (Troppau). It can be translated as "Oh letters, rungs of my research ..."; the poem celebrates Johannes Gutenberg's invention of movable print. Quoted from Iltis $(1924,14)$.
} 
horizon of a polyglot citizen of the Austro-Hungarian Empire and active participant in the vibrant culture of industrializing central Europe. ${ }^{3}$

And yet, the historiography of the life sciences has usually portrayed Mendel as being out of step with his time, either by making him out as the "founding father" of genetics, a quintessentially twentieth-century discipline, or by portraying him as a late representative of "hybridism", a research tradition in the plant sciences deeply rooted in eighteenth-century species fixism. These divergent interpretations are due to what is often called "the long neglect" of Mendel's main literary achievement-a forty-seven pages long report on hybridization experiments with pea and other plant varieties that was published in 1866 . The aim of this publication, as Mendel himself put it, was to establish "a generally valid law for the formation and development of hybrids." ${ }^{4}$ Yet, with some exceptions, this publication went unnoticed until 1900. In that year, three botanists-Hugo de Vries (1848-1935), Carl Correns (1864-1933), and Erich von Tschermak (1871-1962)—claimed to have independently "rediscovered" the law that Mendel had presumably laid down already. Within a few years, his paper, as well as the eponymous laws, became widely known among biologists as

${ }^{3}$ For Mendel's biography, see Iltis (1924, English translation 1966); Orel 1996; and Klein (2013). I will rely on Orel for biographical details throughout this chapter.

${ }^{4}$ Mendel (2016a, p. 3, s. 6). There exist several English translations of Mendel's essay (Mendel 1901; Mendel 1902; Mendel 1966; Mendel 2016b). I am quoting from the latest critical edition and translation, citing page and sentence number. The phrase "long neglect" can be traced back to Glass (1953, p. 148). 
providing the foundations for the new discipline of genetics, a discipline that was perceived to hold revolutionary potential for controlling, manipulating and understanding life. Since then, the thirty-four years of silence around Mendel's paper have either been made out as a tragic case of oversight that hampered scientific progress, or else as a phantasm resulting from anachronistic projections of later scientific developments onto earlier episodes in its history. ${ }^{5}$

Given the curious fate of Mendel's paper, it comes as no surprise that it is one of the most heavily scrutinized texts in the historiography of biology-almost certainly second only to Darwin's On the Origin of Species (1859)—and that the resultant body of scholarly work is ruptured by passionate debates about what it was, exactly, that Mendel discovered, and what place this discovery occupies in the longue durée history of the life sciences in general, and the history of heredity more specifically. No less than three substantive review articles are available, which chart the evolving landscape of these historiographical debates throughout the twentieth century. Their authors-Robert C. Olby, Jan Sapp, and Vítezslav Orel (1926-2015)—fall themselves on different sides of the debates, and yet agree in one fundamental point: They all portray the debates as arising from a divorce between scientist historians looking back at the origins of their

${ }^{5}$ On references to Mendel's paper before 1900, see Olby and Gautrey (1968). On its „rediscovery“ in 1900, see Jahn (1958), Olby (1985, ch. 6), Rheinberger (1995), Stamhuis et al. (1999), Harwood (2000) and Simunek et al. (2011). Olby (1985, 219-234) provides English translations of some sources mentioning Mendel before 1900. On the history of Mendelian genetics, see Dietrich, this volume. 
discipline and professional historians of science deconstructing the resultant "origin myths". 6

This chapter proposes that this picture of a divorce between scientist and professional historians involves elements of mythmaking itself. Whether or not, and if yes, in what sense Mendel can be seen as having brought about a breakthrough in understanding heredity has also been debated among scientists, for the simple reason that the science of heredity, its aims, methods, and core assumptions, was understood and evaluated very differently by different schools and generations of scientists. Mendel's paper became a paradigmatic case in the history of science not simply because its historical meaning was contested, but more specifically because production and reception of a "discovery" sharply fell apart in this case, thus raising fundamental questions about the relationship between scientific achievement and "its" time. In the following, I am going to provide an overview of answers to these questions. I will first cover commentators who have claimed that Mendel was "ahead" of his time, and that contemporaries failed to recognize his achievement. I will then move on to scholars and scientists who argued against this position, claiming that Mendel was not anticipating twentieth-century genetics, but was in fact representative of

${ }^{6}$ Sapp (1990, p. 146); Orel and Hartl (1994, p. 445); Olby (1997, sect. "Scientific Disciplines"). All three review articles are accessible online at MendelWeb (www.mendelweb.org), an internet resource created by Roger B. Blumberg in 1995, but not updated since 1997. It offers a wealth of other useful material, including the German original and Bateson's 1902 translation of Mendel's paper for download. 
an older research tradition. In a last step, I will turn to those who have held that both of these positions rest on a false dichotomy and that Mendel was embedded in a local culture that combined a variety of advanced and traditional strands of nineteenth-century life-sciences. Overall, I am going to argue that one should not overestimate the coherence and dominance of presumed "paradigms", "epistemes" or "styles" in biology. Life, as well as the scientific disciplines that study it, are just too indeterminate and inchoate to develop in such an orderly fashion.

\section{Mendel Ahead of His Time}

The historiography of Mendel begins with his three rediscoveres. All of them acknowledged his priority, and added that his paper had "fallen into oblivion" (de Vries), had "hardly attracted any interest" (Correns), or, as Tschermak put it, only had come to light after its “simultaneous 'discovery' by Correns, de Vries and myself."7 Yet, already in this epochal moment in the history of heredity, disagreements about how to read Mendel became apparent.

De Vries was the first to announce the "discovery" of Mendel in a "preliminary note" that he had submitted for publication on March 14,1900, to the German journal Berichte der deutschen Botanischen Gesellschaft. Without much ado, he

\footnotetext{
7 Vries $(1900,85)$, Correns $(1900,159)$ and Tschermak $(1900,239)$. English translations of de Vries's and Correns' papers can be found in Stern and
} Sherwood (1966, 107-138), but I am here providing my own. 
brought Mendel into the fold of his own mutation theory, claiming that Mendel had only shown for a "special case (peas)" what he, de Vries, had been able to establish with "general validity," namely 1) that hybrids show one of two "antagonistic characters" only (what is sometimes called the law of dominance) and 2) that these characters "separate in the formation of pollen and egg cells" (the law of segregation). ${ }^{8}$

Correns followed suit, with a paper submitted to the same journal on April 24. With thinly veiled sarcasm, he stated that he had not "considered it necessary to secure priority for a 'post-discovery' ['Nach-Entdeckung']." Against de Vries, Correns argued on the basis of actual quotations from Mendel's paper that the latter had not formulated two laws, but only one, which stated "that the hybrids produce germ- and pollen cells that correspond in equal quantities to all the constant forms that emerge from the combination of the traits that were united by fertilisation." What de Vries' called the "law of segregation" (Spaltungsgesetz) was actually included by this law, whereas de Vries's law of dominance was simply fictitious and had never been endorsed by Mendel. ${ }^{9}$

Tschermak went even further in dissociating Mendel from any particular "laws" of inheritance. His contribution to the Berichte, submitted on June 2, did not embark on an interpretation of Mendel's original paper, but simply took his

\footnotetext{
${ }^{8}$ Vries $(1900,84-85)$.

${ }^{9}$ Correns $(1900,166-68)$. Correns quotes Mendel's own formulation of the alleged law; cf. Mendel (2016a, p. 29, s. 4).
} 
empirical results for granted. ${ }^{10}$ A year later, however, Tschermak published the first scholarly edition of Mendel's paper in a renowned book series of classical contributions to natural science. According to him, all that Mendel had shown was that traits of organisms differ regularly in their "valency" (Werthigkeit), and that they do so in three respects: heritability, number of individual carriers, and degree of expression of traits. ${ }^{11}$ His account of how Mendel had been forgotten now showed a slight change in wording. Mendel's paper had not been "discovered" but rather "'rediscovered"” ("wiederentdeckt"; quotation marks in the original). ${ }^{12}$ It is likely that he took over this curious locution from the British botanist William Bateson, who mentioned "de Vries's papers announcing the 'rediscovery' and confirmation of Mendel's law" in the published version of a paper presented to the Royal Horticultural Society on May 8, 1900. Bateson also used the phrase "simultaneous rediscovery" - now without quotation marksabout half a year later in an introductory note that preceded the first English translation of Mendel's paper. ${ }^{13}$

It is worth contemplating these details for two reasons. First, the various uses of the term "discovery," and especially its derivatives, as well as the frequent use of quotation marks indicate that it is a very slippery term, even, and perhaps

10 Tschermak $(1900,235)$.

11 Tschermak $(1901,54)$. In the second edition (1911), Tschermak changed his mind, and presented Mendel much more in line with what we today would consider as conventional Mendelism.

12 Ibid., 55.

${ }^{13}$ Bateson (1900-1901, 60); Mendel $(1901,2)$. 
especially, to scientists. Not only does it seem that scientific discoveries, just like films, can experience "remakes"; the meaning of the term also shifts back and forth between uncovering a timeless fact of nature and lifting a past effort to describe such a fact from the vast archives of modern science. Sociologist of science Augustine Brannigan has argued for an "attributional model of scientific discovery," according to which priority disputes, but more importantly scientific debates about how best to interpret phenomena, provide the social context in which "certain happenings" are declared "discoveries", and the "simultaneous rediscovery" of Mendel by de Vries, Correns and Tschermak served him as a paradigmatic case. ${ }^{14}$ My point here is a different one, though, namely that such processes of attribution also generate among scientists what I suggest to call a "spontaneous" history of science. Even for scientists, facts of nature are inextricably bound up with texts that try to communicate them, and these texts never simply speak for themselves, but always need historical uncovering and interpretation to reveal their proper meaning. ${ }^{15}$

Given the central role genetics played in twentieth-century life sciences, it therefore does not come as a surprise that Mendelian scholarship, to this day, has heavily depended on contributions from scientists. Virtually all the archival sources we possess from Mendel have been unearthed and edited, often with an accompanying scholarly apparatus, not by historians of science, but by scientists:

\footnotetext{
${ }^{14}$ Brannigan $(1979,450)$.
}

15 The French Marxist philosopher Louis Althusser suggested that the "spontaneous philosophy of scientists" could provide an antidote to the tendency of philosophy "to speak about nothing but itself" (Macherey 2009, 19). 
Tschermak and Bateson, as already mentioned, edited and translated his original paper, and Correns soon followed with an edition of the letters Mendel wrote to prominent Swiss botanist Carl Naegeli (1817-1891). ${ }^{16}$ The centennial of Mendel's paper saw another two critical editions, with accompanying materials and commentary by geneticists R. A. Fisher (1890-1962) and Curt Stern (19021981) respectively, and in the same year the Czech poultry geneticist Jaroslav Kříženecký (1896-1964) produced a transcription of Mendel's original fair copy. ${ }^{17}$ Even the few handwritten annotations that have come down to us from Mendel's readings and experiments were brought to light by scientists like the embryologist Sir Gavin de Beer (1899-1972), Dutch botanist and conservationist Jacobus Heimans (1889-1978) or German viticulturalist Franz Weiling (19091999) - not to speak of the countless, and often obscure, primary sources that support the three biographies of Mendel, all of them composed by scientists. ${ }^{18}$

These efforts did not simply aim to celebrate Mendel as the "founding father of genetics". What was also at stake, as we have seen with the rediscoverers, were fundamental questions relating to the nature of Mendel's discovery. In a classic essay, which appeared in the first issue of the journal Annals of Science (1936), the statistician R. A. Fisher formulated these questions succinctly: "What did Mendel discover? How did he discover it? And what did he think he had

\footnotetext{
${ }^{16}$ Correns (1905); Naegeli's responses to Mendel are lost.

17 Bennett (1965); Stern and Sherwood (1966); Kř́iženecký (1965, 57-92).

${ }^{18}$ Beer (1964); Heimans (1970); Weiling (1992). On Mendel biographies, see note 2 .
} 
discovered?"19 And Fisher was all but naïve about the prospect of deciding these questions on an entirely objective basis. His essay was in fact the first historiographical contribution to Mendelian scholarship, and came to the oftquoted conclusion that

Each generation, perhaps, found in Mendel's paper only what it expected to find; in the first period a repetition of the hybridization results commonly reported, in the second a discovery in inheritance supposedly difficult to reconcile with continuous evolution. Each generation, therefore, ignored what did not confirm its own expectations. Only a succession of publications, the progressive building up of a corpus of scientific work, and the continuous iteration of all new opinions seem sufficient to bring a new discovery into general recognition. ${ }^{20}$

The target of this conclusion, and of the article as a whole, was a complex one. It included those (the "first generation") who allegedly had only been interested in the empirical verification of Mendel's experimental results, but also those (the "second generation") who had offered a particular theoretical reading of these results. Fisher's argument was therefore twofold. On the one hand, he rejected the idea-prominently defended by Bateson in the polemical context of what came to be known as the "Mendelism-Biometry debate"21_that Mendel had

\footnotetext{
${ }^{19}$ Fisher $(1936,137)$.

${ }^{20}$ Fisher $(1936,137)$.

${ }^{21}$ Bateson (1902). This was the first book-length critical study of Mendel's paper, and a second revised edition appeared in 1909.
} 
been opposed to Darwin, that Mendel's main achievement had been to disprove continuous variation, and that the dominance of Darwinian ideas had been responsible for his neglect. On the other hand-and now following up on earlier clues from Bateson-, Fisher proposed that Mendel did not at all proceed empirically, as a superficial reading of his paper might suggest. Instead, he had constructed his experiments, as well as the account he gave of them (including some manipulation of data to fit expectations), in order to produce "a carefully planned demonstration of his conclusions."22 Both lines of argument chimed well with Fisher's own contributions to the so-called "Modern Synthesis" of Mendelian genetics with the Darwinian theory of natural selection on the one hand, and to the foundations of mathematical population genetics on the other. ${ }^{23}$ Fisher's essay extended the "long neglect of Mendel” by another full thirty years. ${ }^{24}$ If nineteenth-century researchers had overlooked his results, and what these revealed about the mechanism of inheritance, early twentieth-century Mendelians had misunderstood his unique approach, which combined

${ }^{22}$ Fisher $(1936,124)$. Whether Mendel, consciously or not, „falsified“ his data to produce results that were "too good to be true" has been the subject of a fierce debate among statisticians, geneticists and historians of science that continues to this day; see Franklin et al. (2008) for a collection of important contributions to this debate. The allegation of data manipulation was not new when Fisher wrote his article. Bateson's main opponent, the biometrician Raphael Weldon (18601906), had actually raised it in 1902 already; see Radick (2015).

${ }^{23}$ On the Modern Synthesis, see Borello, this volume.

${ }^{24}$ Beer (1964). 
experiment with mathematical treatment, and had failed to see that it was compatible with Darwinian natural selection. Mendel thus turned into the paradigm case of a scientist who fell out of the discursive boundaries drawn by scientific communities. In 1953, American geneticist H. Bentley Glass produced a map-like diagram for his contribution to a Festschrift honoring Arthur 0. Lovejoy, the "father" of the history of ideas. Bearing the title "The Chain of Ideas from Goethe and Oken, Who Represent the Naturphilosophie, to Modern Genetics," it did not even include Mendel who, as Glass supposed, lay "out to the side of all these streams of thought."25

For the history of heredity more generally, this portrayal of Mendel as a lone and mis- or not-at-all understood researcher had a curious consequence. Books dedicated to this subject, up until the mid-1960s, were of two kinds. They were either histories of genetics, taking their starting point in 1900, the year of rediscovery; ${ }^{26}$ or they were histories of "precursors" to Mendelism, choosing the same year as their vanishing point. ${ }^{27}$ Alongside this, there existed a literature that dealt separately with a related subject: the history of generation. ${ }^{28}$ All of these studies retain their value, both for their sophistication and the wealth of material they contain. The three strands would only be brought together, however, after the Long Neglect story had been seriously challenged in the late 1970s.

\footnotetext{
${ }^{25}$ Glass $(1953,158)$.

${ }^{26}$ Carlson (1966); Sturtevant (1966).

${ }^{27}$ Roberts (1929); Stubbe (1965); Robinson (1979).

${ }^{28}$ Lesky (1951); Roger (1963/1998); Gasking (1967).
} 


\section{Mendel Stuck in Time}

While not themselves contributing to historical scholarship, sociologists and philosophers of science in the first six decades of the twentieth century were quick to pick up the story of Mendel's neglect and subsequent parallel rediscovery. Cultural Anthropologist Alfred L. Kroeber (1876-1960) used it in his article "The Superorganic" (1917)—in which he argued for the independence of cultural evolution from the biological and psychological evolution of individuals - to point to the "the inexorable fate in store for the discoverer who anticipates his time", and such references became routine with later sociologists and anthropologists intrigued by the phenomenon of multiple and roughly simultaneous discoveries and inventions. ${ }^{29}$ In the French tradition of historical epistemology, references to Mendel and his rediscovery were made just as routinely. Thus, Michel Foucault (1926-1984) proclaimed in his inaugural lecture at the Collége de France, held on 2 December 1970, that Mendel had spoken "of objects, employed methods and placed himself within a theoretical perspective totally alien to the biology of his time", and that it would require a "whole change in scale, the deployment of a totally new range of objects in biology ... before Mendel could enter into the true [dans le vrai] and his

${ }^{29}$ Kroeber (1917, 198); Ogburn and Thomas (1922); White (1949). Robert K. Merton (1910-2003), in his classic article on multiple discoveries (1961), considered the "case of Mendel" as "too well known" to even expand on it any further; see Merton (1996, 308). 
propositions appear, for the most part, exact." ${ }^{30}$ In the same year, molecular biologist François Jacob published his magisterial Logic of Life: A History of Heredity, in which Mendel, once more, but now in greater detail, was credited as having introduced an entirely new approach to biology—as well as constituting a new object, the gene-by focusing on discrete character pairs in his experiments and analyzing their results with the help of combinatorial analysis and statistics. $^{31}$

All of these accounts do not divorce scientific achievements from contemporary contexts; quite on the contrary, the point of telling Mendel's story was, and often still is today, to demonstrate how powerful prevailing discursive contexts are in advancing, or else, obstructing innovation. The only way to counter this story, without falling back into sheer positivism, was to say that the story itself was simply wrong; that Mendel had, in fact, not discovered what he was supposed to have discovered sixteen years after his death; that he had not been a "lone genius" but a well-connected naturalist; and that he had not been neglected at his time but received due attention from his peers. In other words, what was called for was a new reading of relevant historical sources for hints that would root Mendel firmly within traditions of nineteenth-century biology.

${ }^{30}$ Foucault $(1971,16)$. The quoted passages rely heavily on earlier work by Foucault's mentor Georges Canguilhem (1904-1995); see, e.g., Delaporte (1994, $37,51)$.

31 Jacob (1970/1996, 202-9). 
Helpfully, Mendel himself was quite explicit in placing himself within such traditions. Not only did he list predecessors in the first paragraph of his paper, but he also concluded it with a critical review of their experiments (again, an exercise in "spontaneous history"). ${ }^{32}$ In a book that appeared in the centennial year 1966, alongside the two new English editions of Mendel's paper mentioned above, Olby followed up these references in a two-pronged attack on the received view of Mendel. Not only did he show that Mendel had been working in a long-established and well-defined older research tradition which dealt with hybridization, rather than heredity as such, and dated back to a hybridization experiment carried out in 1759 by the Swedish naturalist Carl Linnaeus (17071778); it also turned out that heredity as a research subject of its own was not so much defined by Mendel, nor by Charles Darwin who remained a "life-long generation theorist", but by the likes of Francis Galton (1822-1911) and August Weismann (1834-1914).33

Olby was the first professional historian of science to write a monographic account of Mendel and the history of inheritance. As he recalls in the second

${ }^{32}$ Mendel (2016a, 38-47). Interestingly, this last section was left out from what became the most popular English edition of Mendel's paper. It originally appeared as an appendix in Castle (1916, 281-321), and was then reprinted as an inconspicuous brochure by Harvard University Press until 1965. This may be why Zirkle $(1951,99)$, otherwise a very attentive scientist historian, claimed that "Mendel himself described none of the earlier research".

33 Olby $(1966,10)$. On Darwin as a "life long generation theorist", see Hodge (1985). 
edition of his book, Origins of Mendelism had grown out of a PhD thesis project he had undertaken with population geneticist and historian of science Alistair Crombie, who later became known for transferring the concept of "style" from the study of art to the study of science and its history. Aware of his own “'Whiggish', 'presentist' ... tendencies" in the first edition-that is, tendencies to select and evaluate protagonists and events in the history of science in view of their contributions to the current state of art. ${ }^{34}$ - Olby aimed to shift emphasis in his amended second edition "away from a positivist and empiricist interpretation of the history of genetics and toward a constructivist view in which knowledge is seen as under-determined by the facts, their meaning being dependent to an important extent upon the theoretical presuppositions of the observer."35 This shift in emphasis was already evident in a highly influential journal article Olby had published in 1979. It bore the provocative title "Mendel no Mendelian?" and turned far more explicitly against "inflated whiggish interpretations" of Mendel that were prevalent among scientists and in the popular press. Relying on Paul Forman's classical study of mythmaking in the historiography of X-ray crystallography, Olby surmised that the "orthodox view" of Mendel as the founding father of genetics had originated and continued to prevail because "geneticists and plant breeders have introduced mythical elements into their reconstructions of the history of genetics which historians have failed to identify and reject." 36

\footnotetext{
${ }^{34}$ See Jardine (2003) for critical reflections on the concept of "Whig history". 35 Olby (1985, xi-xiv). 36 Olby $(1979,53-54)$.
} 
Less polemical in substance than this may sound, and flanked by the sociological analysis Brannigan provided in the same year, "Mendel no Mendelian?" provided ample historical evidence for a new assessment of Mendel's achievements that inspired a whole new generation of Mendelian scholarship. A consensus emerged over the long run that Mendel had certainly not endorsed the particulate view of genetic factors that was promoted by mid twentieth-century population and molecular genetics, and also had not formulated his "laws" in the same way as modern biology text-books do to this day. ${ }^{37}$ But controversy persisted regarding the question how far back in history Mendel should eventually be pushed. Some, including Olby, argued that Mendel was fully up to date with current problems in contemporary cell and evolutionary biology, but failed to convince his peers that he had come up with a plausible solution. ${ }^{38}$ Others, among them evolutionary biologist Ernst Mayr in a review of Olby's book, identified an element of outdated essentialism in Mendel and sometimes even went as far as claiming that he had written his essay specifically to disprove Darwin's theory of natural selection. ${ }^{39}$ Olby captured the two sides in this controversy nicely, by speaking of the "Darwinian" and the "Linnaean" Mendel. ${ }^{40}$ For the history of heredity more generally, Olby's intervention signaled the end of accounts that assumed that heredity was an obvious problem only waiting for its eventual solution by Mendel and the Mendelians. Jacob had already made the

\footnotetext{
${ }^{37}$ Kampourakis (2015).

38 Campbell (1982); Olby (1985, ch. 5); Sandler and Sandler (1985).

${ }^{39}$ Mayr (1973); Callender (1988); Bishop (1996).

40 Olby (1997), sect. IV, „Mendel and the Darwinians“.
} 
forceful point in 1970 that heredity was a relatively late conceptual product of modern biology, and that its history formed a complex landscape of evolving and competing disciplinary formations. Each "stage" in the history of heredity was characterized by a whole series of conceptual, technological and methodological breakthroughs that made new domains of enquiry accessible to researchers, but also limited them to a "range of possibilities defined not only by current theories and beliefs, but also by the very nature of the objects accessible to investigation, the equipment available for studying them and the way of observing and discussing them." 41 While disagreeing with Jacob's very general, transdisciplinary periodization, evolutionary biologist Ernst Mayr (1904-2005) produced a similar account in his Growth of Biological Thought: Diversity, Evolution, and Inheritance (1982). Like Jacob, he saw biological disciplines going through "periods of stagnation and periods of greatly accelerated advance." 42 Placing emphasis much more exclusively on conceptual shifts than Jacob, Mayr told the history of heredity through shifts along conceptual dichotomies-from essentialism to population thinking, from preformation to epigenesis, from soft (or Lamarckian) to hard inheritance, from blending to non-blending inheritance-that have profoundly influenced subsequent discussions among historians and philosophers of biology. ${ }^{43}$

Despite this influence, or rather just because of it, Mayr attracted substantial criticism from professional historians of science for what they perceived as his

\footnotetext{
${ }^{41} \operatorname{Jacob}(1970 / 1996,11)$

42 Mayr (1982, 127).

43 Burkhardt (1994); Müller-Wille (2011).
} 
"Whiggish" tendency to focus selectively on the history of those ideas that would eventually shape twentieth-century theories of evolution. ${ }^{44}$ A good example is Peter J. Bowler's popular book on the history of hereditarianism, entitled The Mendelian Revolution: The Emergence of Hereditarian Concepts in Modern Science and Society (1989). Bowler agreed that the "advent of Mendelism represented ... a conceptual revolution of major proportions." 45 But drawing inspiration from Thomas S. Kuhn's theory of paradigm change and the Edinburgh School's “strong program" in sociology of knowledge, he emphasized the social and ideological dimensions of this revolution. Especially eugenics, which had hardly played any role in Jacob's and Mayr's histories of heredity, was thus foregrounded as a major force in promoting hereditarian ideas, while Mendel's original contribution receded into the background of the countless efforts in late nineteenth-century biology to conceptualize heredity from the point of view of a "developmentalist" or "pre-Mendelian" paradigm that did not yet separate clearly between transmission and development. "[N]ew laws or theories are not simply 'discovered'," Bowler insisted against scientist historians, but "invented to satisfy the cultural values of the scientists and of the public with whom they interact." Mendel's paper had simply failed to conform to these values at the time when it was published, but happened to do so thirty-four years later. 46

\footnotetext{
${ }^{44}$ Bowler (1988). For a defense against these attacks, see Mayr (1990).

45 Bowler $(1989,7)$.

46 Bowler (1989, 7, 44, and 94-95). Ironically, Bowler relied on an earlier explanation of the "long neglect" that had been proposed by two geneticists, Iris and Laurence Sandler; see Bowler $(1989,108)$.
} 


\section{The Many Times of Mendel}

The idea that Mendel's "discovery" was an invention, or fabrication even, met stubborn resistance above all from one Mendelian scholar: Vítězslav Orel (19262015). Orel was a student of Kříženecký's, and played an important role in preparing the 1965 Gregor Mendel Memorial Symposium in Brno, which was organized by the Czech Academy of Sciences with sponsorship from international organizations such as UNESCO, the International Union of Biological Scientists and the International Atomic Energy Agency. The Symposium attracted an international audience of scientists, including Conrad $\mathrm{H}$. Waddington (1905-1975), Nikolay Timofeev-Ressovsky (1900-1981), as well as Jacob, Stern and Stubbe as speakers. ${ }^{47}$ Subsequently, Orel became the Director of the Mendelianum - a museum dedicated to Mendel's life and work on the premises of the monastery in Brno-, head of a research unit on Mendel at the Agricultural University in Brno, and Editor of a journal entirely devoted to Mendelian scholarship, the Folia Mendeliana. He held these positions until his retirement in 1990, but continued to publish on Mendel until his death in 2015, often in co-authorship with anglophone scientists and historians. ${ }^{48}$

${ }^{47}$ Sosna (1966, vii-xi). The conference proceedings are available from the Wellcome Library's Digital Collections (URL=https://wellcomelibrary.org/item/b18019900).

48 Paleček (2016). Due to complex local developments in post-communist Brno, there are two Mendel museums now in Brno. The Mendelianum was moved to the Moravian Museum, while a new Mendel Museum sponsored by the Masaryck 
It is tempting to dismiss Orel's life-long insistence that Mendel was the "first geneticist" as a sign of the hero worship that scientists easily fall prey to, and that Olby and Bowler criticized so incisively. But the Gregor Mendel Memorial Symposium was not just any commemorative event. It had been organized to achieve the symbolic "rehabilitation" of Mendelism in the Communist Block after the official downfall of Lysenkoism (and Nikita Khrushchev) in $1964 .{ }^{49}$ In order to make this happen, it was essential to secure a substantial connection between Mendel as a historical figure of local significance in Brno, then part of the Communist Block, and twentieth-century genetics as an international science. And something else needed to happen. Just like the Soviet theoretical physicist Boris Hessen (1893-1936) had exposed the social and ideological "roots" of Isaac Newton's Principia in 1931 in order to fend off accusations in his home country that the pursuit of "pure" science was economically and ideologically useless, it had to be shown that Mendel's work as well was firmly grounded in progressive technological and political developments of his time. ${ }^{50}$

University was established in the monastery. Folia Mendeliana continuous to appear (see http://www.mzm.cz/en/folia-mendeliana/), but its contents are unfortunately not yet available online.

${ }^{49}$ Orel (2005). „Rehabilitating“ Mendel was not just an academic question: Kř́ženecký lost his university position in 1948 and even spent eighteen months in jail in 1958 (Orel 1992). At around the same time, Orel lost his job as head of the poultry research unit at the Agricultural University in Brno (Paleček 2016). 50 On Hessen, see Freudenthal and McLaughlin (2009). 
Orel, as well as the many contributors he recruited for Folia Mendeliana, did this to great effect. Their collective efforts revealed that Mendel was not only firmly grounded in hybridism, but operated at the intersection of several additional strands of nineteenth-century scientific culture: Through his training at the University of Vienna under the physicist and mathematician Christian Doppler (1803-1853), Mendel was familiarized with methods of analytic experimentation involving the application of combinatorial analysis and probability theory. His life-long interest in meteorology, documented in several publications, additionally deepened his understanding of methods in descriptive and predictive statistics. At the university of Vienna, he was exposed to the teachings of botanist Franz Unger (1800-1870) who promoted a "physics of the plant organism" that involved experimentation and the search for mathematical laws governing the distribution of organisms in space and time, and throughout his life, Mendel moved in intellectual circles that discussed evolution also for its political implications (tensions between German and Czech nationalists were running high in the Year of Revolution 1848). Unger was also teaching cell theory, and a visit by Jan Purkyňe (1787-1869) to Brno in 1850 contributed further to Mendel's very advanced understanding of fertilization and plant development. Finally, membership in the Brno Sheep-Breeders Society immersed Mendel in long-standing debates among local naturalists, farmers and industrialists about breeding methods and inheritance. These dated back to the early nineteenth century, and Mendel's predecessor as abbot, Cyril Napp (17921867), played a leading role in them. The monastery was, in fact, one of the biggest players in the thriving economy of Brno-the "Manchester of Central 
Europe," as contemporaries called it-and it was Napp who actively encouraged Mendel to pursue his hybridization experiments. ${ }^{51}$

What is crucial about these different strands is the fact that they were independent of each other and that each had its own time of birth, flourishing and decline. While nineteenth-century biologists in the late nineteenth-century did not clearly separate between hereditary transmission and development, breeders already engaged in a well-articulated discourse of heredity in its first few decades. ${ }^{52}$ Doppler's experimental methods were developed in the 1830 s, but such methods only began to infiltrate biology, especially developmental mechanics and biochemistry, in the very late nineteenth century.53 "AustroUngerian" botany had seen its heyday in the 1840 s and 1850 s, but continued to be influential until it waned with increasing acceptance of Darwinian evolution, just as hybridism did. ${ }^{54}$ Questions regarding the cytological basis of sexual reproduction and inheritance, in contrast, were only beginning to be asked at Mendel's time and the field would only see its "watershed moment" in the 1880s. ${ }^{55}$ These strands were largely independent of each other and fail to form a coherent paradigm, and depending on which one accepts as a benchmark,

51 Orel's biography (1996) continues to be the best guide to the large body of literature on these different strands. The first volume of Klein's biography (2013) adds much interesting detail about the German-Czech context of Mendel.

52 Wood and Orel $(2000,2005)$.

53 Allen (2002).

${ }^{54}$ Gliboff (1999); Radick (2011).

55 Farley (1982); Churchill (1987) (Dröscher (2015). 
Mendel appears as "ahead" or "backward" in time. Their conjunction in Mendel's work, by contrast, was certainly unprecedented and remained unique.

On occasion of his retirement, Orel described his scholarly accomplishment as having "pointed out the achievements of Mendel in the special cultural milieu of this country [i.e., Czechoslovakia]."56 And indeed, particularly his work on Mendel's background in breeding resonated very well with a whole wave of projects on the cultural history of heredity that were initiated in the early 2000 s. Various factors motivated these projects. There was first of all the general shift within the discipline of history of science towards a focus on local contexts of knowledge production and the processes of communication and translation that connect these.${ }^{57}$ Secondly, and concomitantly, eugenics and agricultural biology had become subjects of serious historical scrutiny in the 1980s and 1990s, suggesting, as Bowler had most prominently, that any history of heredity not attending to relevant developments in the political, medical and agro-industrial sphere would be essentially incomplete. ${ }^{58}$ Thirdly, and perhaps most importantly, inheritance as a concept in both the social and the life sciences entered a crisis in the early 2000s, raising the prospect that non-genetic, "alternative" inheritance systems might again move center-stage in the sciences. ${ }^{59}$ Writing the history of heredity was a way to escape the conceptual

\footnotetext{
56 Matalova $(1992,118)$.

57 Shapin and Ophir (1991); Dear (1995); Secord (2004).

58 Russell (1986); Allen (1991); Olby (1993); López Beltrán (1994). On the history of eugenics, see Weindling, this volume.

${ }^{59}$ Keller (2000).
} 
grip that the history of genetics had had on its historiography. And it is no coincidence that historians embarked on this project precisely in the moment when biologists as well began to explore inheritance beyond genetics. ${ }^{60}$

A whole range of essay collections and book-length studies, which paint a varied and complex picture of the history of pre-Mendelian heredity, has resulted from this re-orientation. ${ }^{61}$ In terms of methods and approaches, the cultural history of heredity is quite diverse, if not to say, amorphous. But there are a few shared features, such as a focus on the metaphors used to describe reproductive processes. "Heredity" itself is a concept that was imported from legal discourses into the life sciences, and it does not appear to have come into general use in its biological sense before the nineteenth century. ${ }^{62}$ Historians of law, as well as historians of literature who have looked at expert and non-expert discourses of succession and transmission of land, privileges, titles and money, have therefore provided important input to the cultural history of heredity, especially by drawing attention to the multiplicity and complexity of ways in which property (and properties) are transmitted in different historical and cultural contexts. ${ }^{63}$ An emphasis on heterogeneity also characterizes the literature on the cultural history of heredity that has more narrowly focused on conceptions of inheritance

60 See, e.g., Jablonka and Lamb (2005).

${ }^{61}$ For an attempt at a synthetic overview, see Müller-Wille and Rheinberger (2012).

${ }^{62}$ López Beltrán (2004a); cf. Radick (2012).

${ }^{63}$ Weigel, Willer and Jussen (2013); see also Gayon and Wunenberger (1995). 
within the life sciences. When biologists like Darwin and Galton first began to look into heredity in the mid nineteenth-century, they relied on empirical knowledge from very different sources: breeders' tracts on the uses (and dangers) of in- and outbreeding domestic animals; medical treatises like the Traité philosophique et physiologique de l'hérédité naturelle (1847-51), in which the French "alienist" Prosper Lucas (1814-1899) discussed the inheritance of mental disease in two hefty volumes; or the burgeoning literature in physical anthropology, anthropometry and human statistics that had emerged out of the eighteenth-century tradition of a "natural history of mankind." 64 Bowler was right, then, to place emphasis on what he called the "Mendelian" revolution; it was indeed the late nineteenth century in which heredity was consolidated as a widely recognized subject of research, speculation and explicit debate. Unlike Bowler, however, more recent studies have highlighted theoretical pluralism and coexistence of a diversity of research traditions, rather than discursive closure as a key characteristic of this period. ${ }^{65}$

Finally, despite their focus on local contexts of knowledge production and transmission, cultural studies of heredity have also promoted a renewed attention to the longue durée of heredity in its various incarnations. Thus, for some very specific contexts—such as medical theories explaining familial diseases, the breeding of domestic animals, and political and legal debates about the status of nobility-, it has been possible to trace hereditarian ideas as far

\footnotetext{
${ }^{64}$ Müller-Wille and Rheinberger (2007).

65 Rheinberger (2008); Kampourakis (2010).
} 
back as the early fourteenth century. ${ }^{66}$ Continuities proliferate, and extend back even further to the ancient world, inside and outside of Europe, if one casts the net wider, and shifts the focus from the concept of heredity to the broader category of reproduction, hence including disciplines like gynecology and demography. ${ }^{67}$ It is medical practice and theory, in particular, with its inherent political dimension of governing life for the sake of health and its consequent exposure to the contingencies and accidents of "real" life, that challenges the historian's imagination with a bewildering array of co-existing conceptions of heredity, both "ancient" and "modern," at any point of its history. ${ }^{68}$

Seen against this background, modern hereditarian ideas appear less specifically tied to the name of Mendel, but rather associated with the long-drawn processes of nation state formation, the rise of capital and industrialization, as well as European colonialism and imperialism. ${ }^{69}$ The story of Mendel's "long neglect" thus appears less and less as a focal historiographical riddle. Nothing about the sciences of heredity before 1900 seems to exclude Mendel as "abnormal", nor predetermine his "rediscovery" as founding father of a new science at the beginning of the new century. It has therefore become conceivable to think of Mendel's innovation as firmly grounded in the hybridist tradition, and yet taking

${ }^{66}$ Lugt and Miramon (2008).

${ }^{67}$ Hopwood, Flemming and Kassell (in press).

68 Gaudillière and Löwy (2001); Gausemeier, Müller-Wille and Ramsden (2013); Gausemeier (2014).

${ }^{69}$ López Beltrán (2004b); Müller-Wille (2007); Waller (2012); Müller-Wille and Brandt (2016); Porter, in press. 
it a crucial step further by creating an experimental system that later Mendelians could exploit productively. ${ }^{70}$ "Mendel's discovery", in all its different senses, was the result of thoroughly contingent circumstances that fail to fit with a clear taxonomy of "paradigms", "epistemes" or "styles". In the light of current epigenetics and theories of extended inheritance, it therefore seems perfectly possible, that other inheritance mechanisms than genetic transmission could have been foregrounded in the life sciences at the beginning of the last century, and to raise the counterfactual question how twentieth-century life sciences would have developed if Mendelian views of inheritance had not prevailed. ${ }^{71}$ In other words: The central historiographical riddle for the historian of heredity today with regard to "Mendel's discovery" is not anymore why it was neglected but how it could have happened at all.

\section{Outlook}

"History is ... never history, but history-for" according to anthropologist Claude Lévi-Strauss. ${ }^{72}$ We do not tell stories to the dead, but for our contemporaries and in reaction to present situations that have been shaped by past events but do not represent them. ${ }^{73}$ Writing history is therefore an inherently anachronistic practice and conditioned by assumptions about the historicity of the subject of

\footnotetext{
${ }^{70}$ Müller-Wille and Orel (2007); Rheinberger and Müller-Wille (in press).

${ }^{71}$ Radick (2016).

${ }^{72}$ Lévi-Strauss (1962/1966, 257).

${ }^{73}$ Collingwood (1994).
} 
our choice. ${ }^{74}$ Ever since Hessen's exacting demand to understand Newton "in his time", it has become commonplace for historians of science, and eventually part of their professional identity, to accuse "scientist" historians, and each other, of anachronisms. But what defines the time scale against which anachronism is to be determined remains a wide-open question that will be answered differently by different historians. From this perspective, it can be as anachronistic to call Mendel a "Linnaean" as it may be to call him "the first geneticist".

This does not mean that any historical account is legitimate. Misrepresenting sources, ignoring their contexts, and falling back on facile teleological explanations is bad practice, in history as much as in politics. What it means, though, is that we should not be surprised that developments in the sciences themselves, among many other factors, can precipitate major changes in perspective in the history of science, as I have argued for the "cultural history of heredity" in the last section of this chapter. The opening up of biology for a plurality of inheritance systems in the last two decades has drawn attention to a whole range of potential areas of historical inquiry into heredity that we still know far too little about and that I want to outline in conclusion.

One of the ironic results of the long-lasting fixation with Mendel is that we know little about the wide variety of hereditarian ideas around 1900, and especially their legacy in the twentieth century. The little we do know has emerged from the study of debates between Mendelians and other schools of thought and

\footnotetext{
${ }^{74}$ Canguilhem (1966/2005).
} 
practice like the Biometricians or proponents of cytoplasmic inheritance. ${ }^{75}$ But studies of continuing traditions within embryology, cytology or biochemistry in their own right are relatively rare, as are studies that trace back contributions of prominent Mendelians to their formative years before the annus mirabilis 1900. A promising start has been made with attempts to write the history of evolutionary developmental biology (evo-devo), epigenetics and of stem cell research, but many more lacunae-such as the continuing influence of Nägeli on early twentieth-century colloid research-need to be filled before we can even get a clearer picture of how pervasive the dominance of Mendelian genetics actually was in the biological and biomedical sciences of the twentieth century. ${ }^{76}$ A further aspect waiting to be elucidated is the entanglement of heredity with politics. Again, this may come as a surprise, since the many studies that exist on the history of eugenics and scientific racism seem to evince a very clear connection between heredity and politics. These tend, however, to understand "biopolitics" - against the intentions of Michel Foucault who introduced the term-as a politics of the bureaucratic nation state and the scientific elites it coopted, and thus conceal how concepts of inheritance also operate on the more mundane level of families and property transmission. Heredity itself is a very male idea, and its history inseparable from the history of patriarchy. ${ }^{77}$ Yet it is rare that perspectives from gender history and historical anthropology are

\footnotetext{
${ }^{75}$ Sapp (1987); Olby (1989).

76 Laubichler and Maienschein (2007); Barahona et al. (2010); Dröscher (2014).

On Nägeli and colloid chemistry, see Liu (2016, ch. 4).

77 Jordanova (1995).
} 
employed in the study of heredity, and the history of hereditarian ideas in relevant disciplines, such as gynecology and pediatrics, has up until recently hardly figured in the historiography of heredity. ${ }^{78}$ The recent expansion of the cultural history of heredity to a more inclusive cultural history of reproductionno doubt motivated by the rapid development of new reproductive technologies - is bound to open up of new avenues of historical inquiry in this respect, and historical anthropologists and social anthropologists have a wealth of conceptual tools to offer for such inquiries. ${ }^{79}$

A final area in the cultural history of heredity of which we know too little concerns ideas and practices in non-European and pre-modern contexts. To wit, various attempts to explain similarities between parents and their children are well-covered for some of the more prominent early modern natural philosophers. ${ }^{80}$ However, the vast domains of medical and agricultural literature, which pre-modern Europe and other civilizations such as the Arab-Islamic world or China produced, have hardly been touched upon by scholars with a specific view on heredity. ${ }^{81}$ One may argue as some have done, including the author of this chapter, that heredity is a concept that simply did not exist outside of modern Europe. But that may itself just reflect a historical bias that was brought about by Mendel's discovery.

\footnotetext{
78 See Arni (2015) for an interesting exception.

${ }^{79}$ Franklin (2013); Sabean et al. (2013).

${ }^{80}$ Smith (2006).

${ }^{81}$ For notable exceptions, see Lugt (2004) and López-Beltrán (2007).
} 


\section{References}

Allen, Garland E. "Essay Review: History of Agriculture and the Study of Heredity

- a New Horizon." Journal of the History of Biology 24 (1991): 529-36.

Allen, Garland E. “The Changing Image of Biology in the Twentieth Century.” In:

The Changing Image of Science, edited by Ida H. Stamhuis, Teun Koetsier,

Cornelis De Pater, and Albert Van Helden. Dordrecht: Kluwer Academic, 2002, pp. 43-83.

Caroline Arni. "Traversing Birth: Continuity and Contingency in Research on

Development in Nineteenth-Century Life and Human Sciences." History and Philosophy of the Life Sciences, 37 (2015), 50-67.

Barahona, Ana, Edna Suarez-Díaz, and Hans-Jörg Rheinberger (Eds.). The

Hereditary Hourglass. Genetics and Epigenetics, 1868-2000. Preprint 392. Berlin:

Max Planck Institute for the History of Science, 2010.

Bateson, William. "Problems of Heredity as a Subject for Horticultural Investigation." Journal of the Royal Horticultural Society 25 (1900-1901): 54-61.

Beer, Gavin de. “Mendel, Darwin, and Fisher (1865-1965)." Notes and Records of the Royal Society of London 19 (1964): 192-226.

Bennett, J. Henry (Ed.). Gregor Mendel. Experiments in Plant Hybridization. Mendel's Original Paper in English Translation with Commentary and Assessment by the late Sir Ronald Fisher. Edinburgh and London: Oliver \& Boyd, 1965. 
Bishop, B. E. “Mendel's Opposition to Evolution and to Darwin." Journal of Heredity 87 (1996): 205-13.

Bowler, Peter J. The Non-Darwinian Revolution: Reinterpreting a Historical Myth. Baltimore: John Hopkins University Press, 1988.

Bowler, Peter J. The Mendelian Revolution: The Emergence of Hereditarian Concepts in Modern Science and Society. Baltimore: John Hopkins University Press, 1989.

Brannigan, A. “The Reification of Mendel." Social Studies of Science 9 (1979): 423-54.

Burkhardt, Richard W. "Ernst Mayr: Biologist-Historian." Biology and Philosophy 9 (1994): 359-71.

Callender, L. A. “Gregor Mendel: An Opponent of Descent with Modification.” History of Science 26 (1988): 41-75.

Campbell, Margaret. "Mendel's Theory: Its Context and Plausibility." Centaurus 26 (1982): 38-69.

Canguilhem, Georges. "The Object of the History of Sciences.” In Continental Philosophy of Science, edited by Gary Gutting, pp. 198-207. Oxford: Blackwell, 2005. Originally published in French, 1966.

Carlson, Elof Axel. The Gene: A Critical History. Philadelphia: Saunders, 1966. 
Castle, William E. Genetics and Eugenics: A Textbook for Students of Biology and a Reference Book for Animal and Plant Breeders. Cambridge, Mass.: Harvard University Press.

Churchill, Frederick. "From Heredity Theory to 'Vererbung': The Transmission Problem, 1850-1915." Isis 78 (1987): 337-64.

Collingwood, Robin G. The Idea of History, revised edition, edited by Jan van der Dussen. Oxford: Oxford University Press, 1994.

Correns, Carl. “G. Mendels Regel über das Verhalten der Nachkommenschaft der Rassenbastarde." Berichte der Deutschen Botanischen Gesellschaft 18 (1900): $158-68$.

Correns, Carl (Ed.). Gregor Mendels Briefe an Carl Nägeli, 1866-1873. Ein Nachtrag zu den veröffentlichten Bastardierungsversuchen Mendels. Leipzig: Teubner, 1905.

Dear, Peter. "Cultural History of Science: An Overview with Reflections." Science, Technology, \& Human Values 20 (1995): 150-70.

Delaporte, François (ed.). A Vital Rationalist. Selected Writings from George Canguilhem. New York: Zone Books, 1994.

Dröscher, Ariane. “Images of Cell Trees, Cell Lines, and Cell Fates: The Legacy of Ernst Haeckel and August Weismann in Stem Cell Research." History and Philosophy of the Life Sciences 36 (2014): 157-86. 
Dröscher, Ariane. „Gregor Mendel, Franz Unger, Carl Nägeli and the magic of numbers." History of Science 54 (2015): 492-508.

Farley, John. Gametes and Spores: Ideas about Sexual Reproduction. 1750-1914. Baltimore - London: John Hopkins Univ. Pr., 1982.

Fisher, Ronald A. "Has Mendel's Work Been Rediscovered?" Annals of Science 1 (1936): 115-37.

Foucault, Michel. „Orders of Discourse [transl. Rupert Swyer].“ Social Science Information 10 (1971): 7-30. Originally published in French, 1970.

Franklin, Allan, A. W. F. Edwards, Daniel J. Fairbanks, and Daniel L. Hartl (Eds.). Ending the Mendel-Fisher Controversy. Pittsburgh: University of Pittsburgh Press (2008).

Franklin, Sarah. Biological Relatives - IVF, Stem Cells and the Future of Kinship. Durham, NC: Duke University Press, 2013.

Freudenthal, Gideon, and Peter McLaughlin (Eds.). The Social and Economic Roots of the Scientific Revolution. Texts by Boris Hessen and Henryk Grossmann. Vol. 278, Boston Studies in the Philosophy of Science. Heidelberg: Springer, 2009.

Gasking, Elizabeth. Investigations into Generation 1651-1828. London: Hutchinson, 1967.

Gaudillière, Jean Paul, and Ilana Löwy (Eds.). Heredity and Infection: The History of Disease Transmission. London: Routledge, 2001. 
Gausemeier, Bernd. "Pedigrees of Madness: The Study of Heredity in Nineteenth and Early Twentieth Century Psychiatry." History and Philosophy of the Life Sciences 36 (2014): 467-83.

Gausemeier, Bernd, Staffan Müller-Wille, and Edmund Ramsden (Eds.). Human Heredity in the Twentieth Century. London: Pickering and Chattoo, 2013.

Gayon, Jean and Jean-Jacques Wunenburger (Eds.). Le paradigme de la filiation. Paris: L'Harmattan, 1995.

Glass, H. Bentley. „The Long Neglect of Scientific Discovery: Mendel's Laws of Inheritance“. In Johns Hopkins History of Ideas Club, Studies in Intellectual History, pp. 148-160. Baltimore: Johns Hopkins Press, 1953.

Gliboff, Sander. "Gregor Mendel and the Laws of Evolution." History of Science 37 (1999): 217-35.

Hacking, Ian. "'Style’ for Historians and Philosophers.” Studies in History and Philosophy of Science, 23 (1992): 1-20.

Harwood, Jonathan. "The Rediscovery of Mendelism in Agricultural Context: Erich von Tschermak as Plant-Breeder." Comptes Rendus de l'Académie des Sciences - Series III - Sciences de La Vie 3232 (2000): 1061-67.

Heimans, Jacobus. „Ein Notizblatt aus dem Nachlass Gregor Mendels mit Analysen eines seiner Kreuzungsversuche." Folia Mendeliana 4 (1968): 5-36.

Heimans, Jacobus. “A Recently Discovered Note on Hybridization in Mendel's Handwriting." Folia Mendeliana 5 (1970), pp. 13-24. 
Hodge, Jonathan. "Darwin as a Lifelong Generation Theorist." In The Darwinian Heritage, edited by David Kohn. Princeton: Princeton University Press, 1985, pp. , 204-44.

Hopwood, Nick, Rebecca Flemming and Lauren Kassell (Eds.). Reproduction: Antiquity to the Present Day. Cambridge: Cambridge University Press, in press.

Iltis, Hugo. Gregor Johann Mendel: Leben, Werk und Wirkung. Berlin: Springer, 1924.

Iltis, Hugo. Life of Mendel, transl. E. and C. Paul. London: Allen \& Unwin, 1966.

Jacob, François. The Logic of Life: A History of Heredity, transl. B. E. Spillman. Princeton, N. J.: Princeton University Press, 1996. Originally published in French, 1970.

Jahn, Ilse. "Zur Geschichte der Wiederentdeckung der Mendelschen Gesetze." Wissenschaftliche Zeitschrift der Friedrich-Schiller Universität Jena, MathematischNaturwissenschaftliche Reihe 7 (1958): 2155-27.

Jardine, Nicholas (2003). “Whigs and Stories: Herbert Butterfield and the Historiography of Science." History of Science 41 (2003): 125-40.

Jordanova, Ludmilla. "Interrogating the Concept of Reproduction in the Eighteenth Century." In Conceiving the New World Order, edited by Faye D. Ginsburg and Rayana Rapp, pp. 369-86. Berkeley: University of California Press, 1995. 
Kampourakis, Kostas. "Mendel and the Path to Genetics: Portraying Science as a Social Process." Science \& Education 22 (2010): 293-324.

Kampourakis, Kostas. "Myth 16. That Gregor Mendel Was a Lonely Pioneer of Genetics, Being Ahead of His Time“. In: Newton's Apple and Other Myths about Science, edited by Ronald L Numbers and Kostas Kampourakis. Cambridge, Mass.: Harvard University Press, 2015, pp. 129-38.

Keller, Evelyn Fox. The Century of the Gene. Cambridge, Mass.: Harvard University Press, 2000.

Klein, Jan, and Norman Klein. Solitude of a Humble Genius - Gregor Johann Mendel, Vol. 1: Formative Years. Berlin: Springer, 2013.

Kř́ženecký, Jaroslav (Ed.). Fundamenta Genetica: The Revised Edition of Mendel's Classical Paper with a Collection of 27 Papers Published During the Rediscovery Era. Brno: Moravian Museum, 1965.

Kroeber, A. L. “The Superorganic.” American Anthropologist, New Series, 19 (1917): 163-213.

Laubichler, Manfred Dietrich, and Jane Maienschein (Eds.). From Embryology to Evo-Devo: A History of Developmental Evolution. Cambridge, Mass: MIT Press, 2007.

Lesky, Erna. Die Zeugungs- und Vererbungslehren der Antike und ihr Nachwirken. Abhandlungen der geistes- und sozialwissenschaftlichen Klasse der Akademie der Wissenschaften und der Literatur in Mainz, Nr. 19. Wiesbaden: Franz Steiner, 1951. 
Lévi-Strauss, Claude. The Savage Mind. London: Weidenfeld and Nicolson, 1966. Originally published in French, 1962.

Liu, Daniel. Visions of Life and Matter: Protoplasm, Scientific Microscopy, and the Origins of Molecular Biology, 1839-1941. PhD Thesis. University of WisconsinMadison, 2016.

López Beltrán, Carlos. “Forging Heredity: From Metaphor to Cause, a Reification Story." Studies in the History and Philosophy of Science 25 (1994): 211-235.

López Beltrán, Carlos. “In the Cradle of Heredity: French Physicians and L'Hérédité Naturelle in the Early Nineteenth Century." Journal of the History of Biology 37 (2004a): 39-72.

López-Beltrán, Carlos. El Sesgo Hereditario : Ámbitos Históricos Del Concepto de Herencia Biológica. Mexico City: Universidad Nacional Autónoma de México, 2004b.

López Beltrán, Carlos. "Hippocratic Bodies, Temperament and Castas in Spanish America (1570-1820)." Journal of Spanish Cultural Studies 8 (2007): 253-89.

Lugt, Maaike van der. Le ver, le démon et la vierge. Les théories médiévales de la génération extraordinaire. Paris : Belles Lettres, 2004.

Lugt, Maaike van der, and Charles de Miramon (Eds.). L'hérédité entre Moyen Age et époque moderne. Florence: SISMEL-Edizioni del Galluzzo, 2008.

Macherey, Pierre. "Althusser and the Concept of a Spontaneous Philosophy of Scientists." Parrhesia 6 (2009): 14-27. 
Matalová, Anna. "Vítězslav Orel, Chairman of the Mendelianum, Retired." Folia Mendeliana 26-27 (1991-92): 118-119.

Mayr, Ernst. "The Recent Historiography of Genetics." Journal of the History of Biology 6 (1973): 125-54.

Mayr, Ernst. The Growth of Biological Thought: Diversity, Evolution and Inheritance. Cambridge, Mass.: Belknap Press, 1982.

Mayr, Ernst. “When Is Historiography Whiggish?” Journal of the History of Ideas 51 (1990): 301-9.

Mendel, Gregor. “Versuche über Pflanzen-Hybriden.” Verhandlungen des Naturforschenden Vereines zu Brünn 4 (1866): 3-47.

Mendel, Gregor. "Experiments in Plant Hybridization. With an Introductory Note by W. Bateson, M.A., F.R.S." Journal of the Royal Horticultural Society 26 (1901, Part I): 1-32.

Mendel, Gregor. "Experiments in Plant-Hybridisation.” In William Bateson, Mendel's Principles of Heredity: A Defence. Cambridge: At the University Press, 1902, pp. 40-95.

Mendel, Gregor. "Experiments on Plant Hybrids,” translated by Eva R. Sherwood. In: The Origin of Genetics: A Mendel Source Book, edited by Curt Stern and Eva R. Sherwood. San Francisco: W. H. Freeman 1966, pp. 1-48.

Mendel, Gregor. Experiments on Plant Hybrids (1866). Translation and commentary by Staffan Müller-Wille and Kersten Hall. British Society for the 
History of Science Translation Series, 2016a.

URL=http://www.bshs.org.uk/bshs-translations/mendel.

Mendel, Gregor. "Experiments on Plant Hybrids," translated by Scott Abbott and Daniel J. Fairbanks. Genetics 204 (2016b): 407-22.

Merton, Robert K. On Social Structure and Science. Chicago: University of Chicago Press, 1996.

Müller-Wille, Staffan. "Hybrids, Pure Cultures, and Pure Lines: From Nineteenth-

Century Biology to Twentieth-Century Genetics." Studies in History and

Philosophy of Biological and Biomedical Sciences 38, (2007): 796-806.

Müller-Wille, Staffan. “Making Sense of Essentialism.” Critical Quarterly 53 (2011): 61-67.

Müller-Wille, Staffan, and Vitezslav Orel. “From Linnaean Species to Mendelian Factors: Elements of Hybridism, 1751-1870." Annals of Science 64 (2007): 171215.

Müller-Wille, Staffan, and Hans-Jorg Rheinberger (Eds.). Heredity Produced. At the Crossroad of Biology, Politics and Culture, 1500-1870. Cambridge, Mass.: MIT Press, 2007.

Müller-Wille, Staffan, and Hans-Jörg Rheinberger. A Cultural History of Heredity. Chicago: University of Chicago Press, 2012.

Ogburn, William F., and Dorothy Thomas. "Are Inventions Inevitable? A Note on Social Evolution." Political Science Quarterly 37 (1922): 83-98. 
Olby, Robert C. Origins of Mendelism. New York: Schocken Books, 1966.

Olby, Robert C. “Mendel No Mendelian?” History of Science 17 (1979): 53-72.

Olby, Robert C. Origins of Mendelism, second edition. Chicago: University of Chicago Press, 1985.

Olby, Robert. "The Dimensions of Scientific Controversy: The BiometricMendelian Debate." The British Journal for the History of Science 22 (1989): 299320.

Olby, Robert C. “Constitutional and Hereditary Disorders.” In Companion Encyclopedia of the History of Medicine, edited by William F. Bynum and Roy Porter, 412-37. London: Routledge, 1993.

Olby, Robert C. "Mendel, Mendelism and Genetics." MendelWeb 1997. URL= http://www.mendelweb.org/MWolby.html (last accessed January 2, 2016).

Olby, Robert and Peter Gautrey. "Eleven References to Mendel before 1900." Annals of Science 24 (March, 1968): 7-20.

Ophir, Adi, and Steven Shapin. "The Place of Knowledge: A Methodological Survey." Science in Context 4 (1991): 3-22.

Orel, Vítězslav. “Jaroslav Krizenecky (1896-1964), Tragic Victim of Lysenkoism in Czechoslovakia." The Quarterly Review of Biology 67 (1992): 487-94.

Orel, Vítězslav. Gregor Mendel: The First Geneticist. Oxford: Oxford University Press, 1996. 
Orel, Vítězslav. Contested memory: Debates over the nature of Mendel's paradigm. Hereditas 142 (2005): 98-102.

Orel, Vítězslav, and Daniel L. Hartl. "Controversies in the Interpretation of Mendels Discovery." History and Philosophy of Life Sciences 16 (1994): 436-55.

Paleček, Pavel. "Vítězslav Orel (1926-2015): Gregor Mendel’s Biographer and the Rehabilitation of Genetics in the Communist Bloc." History and Philosophy of the Life Sciences 38 (2016): 4. doi:10.1007/s40656-016-0104-3.

Porter, Theodore. The Unknown History of Human Heredity. Princeton: Princeton University Press, in press.

Radick, Gregory. "Physics in the Galtonian Sciences of Heredity.” Studies in History and Philosophy of Biological and Biomedical Sciences 42 (2011): 129-38.

Radick, Gregory. “Should 'Heredity' and 'Inheritance’ Be Biological Terms?

William Bateson's Change of Mind as a Historical and Philosophical Problem." Philosophy of Science 79 (2012): 714-24.

Radick, Gregory. "Beyond the 'Mendel-Fisher Controversy.'” Science 350 (2015): $159-60$.

Radick, Gregory. „Presidential Address: Experimenting with the Scientific Past.“ British Journal for the History of Science 49 (2016): 153-172.

Rheinberger, Hans-Jörg. “When Did Carl Correns Read Gregor Mendel's Paper: A Research Note." Isis 86 (1995): 612-16. 
Rheinberger, Hans-Jörg (2008). „Heredity and its entities around 1900.“ Studies in History and Philosophy of Science, 39 (2008): 370-374.

Rheinberger, Hans-Jörg and Staffan Müller-Wille. The Gene: From Genetics to Postgenomics. Chicago: University for Chicago Press, in press.

Roberts, Herbert F. Plant Hybridization before Mendel. New York: Hafner, 1929.

Robinson, Gloria. A Prelude to Genetics: Theories of a Material Substance of Heredity, Darwin to Weismann. Lawrence, Kansas: Coronado Press, 1979.

Roger, Jacques. The Life Sciences in Eighteenth-Century French Thought, ed. Keith Benson, transl. Robert Ellrich. Stanford, Cal.: Stanford University Press, 1998. Originally published in French, 1963.

Russell, Nicholas. Like Engend'ring like: Heredity and Animal Breeding in Early Modern England. Cambridge: Cambridge University Press, 1986.

Sabean, David Warren, Simon Teuscher, and Jon Mathieu (Eds.). Kinship In Europe: Approaches to Long-Term Development (1300-1900). New York: Berghahn, 2013.

Sandler, Iris, and Laurence Sandler. "A Conceptual Ambiguity That Contributed to the Neglect of Mendel's Paper." History and Philosophy of the Life Sciences 7 (1985): 3-70.

Sapp, Jan. Beyond the Gene. Cytoplasmatic Inheritance and the Struggle for Authority in Genetics. Oxford: Oxford University Press, 1987. 
Sapp, Jan. “The Nine Lives of Gregor Mendel.” In: Experimental Inquiries Historical, Philosophical and Social Studies of Experimentation in Science, edited by H. E. Le Grand. Dordrecht: Kluwer Academic Publishers, 1990, pp. 137-66.

Secord, James A. “Knowledge in Transit." Isis 95 (2004): 654-72.

Simunek, Michal, Uwe Hoßfeld, and Volker Wissemann. “'Rediscovery’ Revised: The Cooperation of Erich and Armin von Tschermak-Seysenegg in the Context of the 'Rediscovery' of Mendel's Laws in 1899-1901." Plant Biology 13 (2011): 835-41.

Smith, Justin E. H. (Ed.). The Problem of Animal Generation in Early Modern Philosophy. Cambridge: Cambridge University Press, 2006.

Sosna, Milan (Ed.). G. Mendel Memorial Symposium 1865-1965: Proceedings of a Symposium held in Brno, August 4-7, 1965. Prague: Academia, 1966.

Stamhuis, Ida, Onno G. Meijer, and Erik J. A. Zevenhuizen. "Hugo de Vries on Heredity, 1889-1903: Statistics, Mendelian Laws, Pangenes, Mutations." Isis 90 (1999): 238-67.

Stern, Curt and Eva R. Sherwood (Eds.). The Origin of Genetics: A Mendel Source Book, San Francisco: W. H. Freeman, 1966.

Stubbe, Hans. Kurze Geschichte der Genetik bis zur Wiederentdeckung der Vererbungsregeln Gregor Mendels. Vol. 2/1 of Genetik. Grundlagen, Ergebnisse und Probleme in Einzeldarstellungen. Jena: VEB Fischer, 1963. 
Sturtevant, Alfred Henry. A History of Genetics. Modern Perspectives in Biology. New York: Harper and Row, 1966.

Tschermak, Erich. “Über künstliche Kreuzung bei Pisum sativum.” Berichte der Deutschen Botanischen Gesellschaft 18 (1900): 232-39.

Tschermak, Erich (Ed.). Versuche über Pflanzenhybriden. Zwei Abhandlungen (1865 und 1869) von Gregor Mendel. Ostwald's Klassiker der exakten Naturwissenschaften. Nr. 121. Leipzig: Wilhelm Engelmann, 1901.

de Vries, Hugo. “Das Spaltungsgesetz Der Bastarde (Vorläufige Mitteilung).” Berichte der Deutschen Botanischen Gesellschaft 18 (1900): 83-90.

Waller, John. Breeding: The Human History of Heredity, Race, and Sex. Oxford: Oxford University Press, 2012.

Weigel, Sigrid, Stefan Willer, and Bernhard Jussen (Eds.). Erbe:

Übertragungskonzepte zwischen Natur und Kultur. Berlin: Suhrkamp, 2013.

Weiling, Franz. “Zur zeitlichen Datierung des genetischen 'Notizblattes' Johann Gregor Mendels." Folia Mendeliana 26-27 (1992): 17-26.

White, Leslie A. The Science of Culture, a Study of Man and Civilisation. New York: Grove Press (1949).

Parnes, Ohad, Ulrike Vedder, and Stefan Willer. Das Konzept der Generation: Eine Wissenschafts- und Kulturgeschichte. Frankfurt a. M.: Suhrkamp, 2008.

Wood, Roger, and Vítězslav Orel. Genetic Prehistory in Selective Breeding. A Prelude to Mendel. Oxford: Oxford University Press, 2001. 
Wood, Roger, and Vítězslav Orel. "Scientific Breeding in Central Europe during the Early Nineteenth Century: Background to Mendel's Later Work." Journal of the History of Biology 38 (2005): 239-72.

Zirkle, Conway. "Gregor Mendel and His Precursors." Isis 42 (1951): 97-104. 